\title{
What does women's empowerment have to do with malnutrition in Sub-Saharan Africa? Evidence from demographic and health surveys from 30 countries
}

\author{
Sanni Yaya ${ }^{1,2^{*}}$ (D), Emmanuel Kolawole Odusina ${ }^{3}$, Olalekan A. Uthman ${ }^{4}$ and Ghose Bishwajit ${ }^{1}$
}

\begin{abstract}
Background: The reduction of childhood malnutrition has been identified as a priority for health and development in sub Saharan African countries. The association between women's empowerment and children's nutritional status is of policy interest due to its effect on human development, labour supply, productivity, economic growth and development. This study aimed to determine the association between women's empowerment and childhood nutritional status in sub Saharan African countries.

Methods: The study utilized secondary datasets of women in their child bearing age (15-49years) from the latest Demographic and Health Survey (DHS) conducted in 2011-2017 across 30 sub Saharan Africa countries. The outcome variable of the study was childhood nutritional status while the exposure variable was women's empowerment indicators such as decision making and attitude towards violence. Analyses were performed at bivariate level with the use of chi square to determine association between outcome and exposure variables and at multivariate level with the use of regression models to examine the effect of women's empowerment on childhood nutritional status.

Results: Women's socio-demographic and other selected characteristics were statistically significantly associated with childhood nutritional status (stunted and underweight) at $p<0.001$. These characteristics were also statistically significantly associated with empowerment status of women (Decision-making, Violence attitudes and Experience of violence) at $p<0.001$ except for child age and sex. The association between childhood nutritional statuses and women's empowerment (all three empowerment measures) was significant after controlling for other covariates that could also influence childhood nutrition statuses at $p<001$. Two of the empowerment measures (attitudes towards violence and experience of violence) showed positive association with childhood nutritional statuses while the third (decision-making) showed negative association.
\end{abstract}

Conclusion: There is an independent relationship between childhood nutrition status and women's empowerment in sub Saharan African countries. Women's empowerment was found to be related to childhood nutritional status. Policies and programmes aiming at reducing childhood malnutrition should include interventions designed to empower women in Sub-Saharan Africa.

Keywords: Women's empowerment, Stunting, Underweight, Childhood nutrition, Global health, Sub Saharan Africa

\footnotetext{
* Correspondence: sanni.yaya@uOttawa.ca

${ }^{1}$ School of International Development and Global Studies, University of

Ottawa, 120, University Private, Ottawa, ON K1N 6N5, Canada

${ }^{2}$ The George Institute for Global Health, The University of Oxford, Oxford, UK

Full list of author information is available at the end of the article
}

(c) The Author(s). 2020 Open Access This article is distributed under the terms of the Creative Commons Attribution 4.0 International License (http://creativecommons.org/licenses/by/4.0/), which permits unrestricted use, distribution, and reproduction in any medium, provided you give appropriate credit to the original author(s) and the source, provide a link to the Creative Commons license, and indicate if changes were made. The Creative Commons Public Domain Dedication waiver (http://creativecommons.org/publicdomain/zero/1.0/) applies to the data made available in this article, unless otherwise stated. 


\section{Background}

In spite of the worldwide improvement in nutritional status of children [1-3] especially in developing countries [4, 5], malnutrition in childhood is still a major health challenge in low income countries [6] and also in the world at large [1, 7]. Child under nutrition is a factor in more than three million preventable childhood deaths. Estimation indicated about 165 million under 5 children are stunted while wasting accounted for 52 million $[1,2]$. Globally, $45 \%$ of child mortality is due to malnutrition $[8,9]$. In 2015, estimates put the number of child mortality due to malnutrition at $405700[1,8]$. Due to persisting malnutrition, the World Health Organisation called for worldwide action to stem down the tide of stunting among children by $40 \%$ by $2025[8,9]$.

Malnutrition contributes substantially to childhood mortality and morbidity in sub-Saharan African countries [10]. Sub-Saharan countries are notable for one of the worst cases of wasting among children, low level of birth weight and underweight. The state of malnutrition in sub Saharan Africa is alarming and requires urgent policies and programmes to alleviate the scourge [11]. In addition, among 162 million stunted under five children, $36 \%$ resided in Africa. In fact, Black et al. [1] and $\mathrm{Na}$, Jennings, Talegawkar and Ahmed [3] put the figure at approximately $40 \%$.

Overall, developing countries had an estimated 60 million under five stunted children [12]. it was also observed that wasting increased from $11 \%$ in 2003 to $18 \%$ in 2013 , underweight from $24 \%$ in 2003 to $29 \%$ in 2013 while stunted decrease from $42 \%$ in 2003 to $37 \%$ in 2013 [12]. The rate of malnutrition is a serious source of concern and also due to its potential effect in the later years of children. Early childhood malnutrition could be a potential cause of low cognitive skills, and resultant low productivity and income-earning ability, vulnerability to chronic diseases and obesity when adult age is attained [13-21]. Therefore, reduction in malnutrition can be of health and economic gain. Existing evidence on factors associated with malnutrition and child health in low income countries emphasised cultural, economic, social and/or infrastructural factors at community, household and individual levels [13, 22-24]. Towards findings determinants of childhood health and malnutrition, studies have also focus on many variables such as domestic violence, maternal education and other maternal characteristics [13, 22, 24, 25]. Of all the factors associated with childhood health and malnutrition, contextually, maternal characteristics such as age, literacy, employment, income and education have been found to be significant $[13,25,26]$.

Evidences revealed studies on relationship between women's empowerment and childhood malnutrition [2, $3,27,28]$. However, more needs to be done in sub Saharan African countries to identify factors and conditions promoting incidence of childhood malnutrition in the region due to high level of childhood malnutrition. An effort towards eliminating childhood malnutrition worldwide would consider sub Saharan Africa as a strong study area to know the associated factors, principal causes and solutions. In addition, data on malnutrition among children in Africa are limited [29]. Though study revealed female labour force participation was not related to malnutrition after controlling for economic development and that women's empowerment and wellbeing might not be a function of women's employment [30]. Literature advocated women's empowerment as a means of improving nutritional status of children. Women empowerment being a concept with multi-dimensional measurement $[13,25]$ and its association with childhood malnutrition has not being adequately explored.

Empowerment as a concept has also been given multidimensional explanations and features [13, 31, 32]. Among many explanations of the concept is the assertion that empowerment entails access, capability to make choice and control over resources [32] while Malhotra, Schuler and Boender argued that patriarchal systems transformation is a prerequisite for achievement of women empowerment [33]. As put forward by Kabeer [32], empowerment connotes a process of change and ability to exercise choice in one's life by people who had earlier on deprived of such opportunities. She opined that there was association between disempowerment and poverty. People with limited resources may find it difficult to exercise meaningful choice, though not all choices are equally relevant to empowerment. She looked at ability to exercise choice from three interrelated ways (resources, agency and achievements). By resources she referred to material, social and human resources that facilitate the capacity to make choice and this can be acquired through social relationship in different institutions of the society. People are endowed with ability to make choice due to their position within the society. Agency refers to ability to recognise and the capacity to pursue one's life goals despite opposition from others. It also refers to capacity to override other through coercion, threat and violence. Sen explained the two terms (resources and violence) as the potential to live according to one's desire and to achieve valued ways of living recognised and valued in the society. He called them 'functioning achievements', all ways of life valued by the society [34]. However, Kabeer [32] reiterated that the three dimensions of empowerment are indivisible. As evident from literature, this study examined three domains of women empowerment and their association with childhood nutritional status [31, 35]. The ability of women to participate in decision making especially in line with resource control and their attitude and experience of violence may affect their lives and 
also reflect on the nutritional status of children. Women empowerment in the past had been measured using proxies like women's education and labour force participation rate which only reflect access to resources but not ability to control or take decision as regard the resources [36].

This study considers datasets from 30 sub-Saharan African countries to do in-depth statistical analysis of women's empowerment and its association with childhood nutritional status. It assesses the relationship between women's empowerment and childhood nutritional status as well as other predictors of childhood malnutrition in the continent.

\section{Methods}

\section{Study design and data source}

This cross-sectional study used data collected from women (15-49 years) of reproductive ages from the latest Demographic and Health Surveys (DHS) conducted between 2011 and 2017 across 30 countries of sub Saharan Africa (see Table 1 for survey characteristics). DHS was designed to collect and provide data on demographic, fertility and family planning as well as information necessary to monitor population health indicators and vital statistics. Demographic and Health Surveys (DHS) are national and representative with special interest on reproductive health, child health, fertility, nutrition, mortality and health behaviour [37]. Data collected through DHS are robust, help in health research and are used to study and monitor prevalence, pattern and trends. To select the sample, multi-stage stratified cluster sampling method was employed and the eligible respondents were selected from rural and urban areas in the country. Data were related to households, women, men, couples and children were collected by means of different questionnaires. Standard methods were employed to test the validity and reliability of the questionnaires. Information, scope and other related concepts of the Demographic and Health Surveys (DHS) are well documented [38]. Demographic and health Surveys (DHS) datasets are available for researchers through DHS at http://dhsprogram.com/data/available-datasets.cfm.

Determinants of childhood nutritional status for under-five children in sub Saharan African countries were estimated by focusing on women's empowerment. Women's empowerment was measured by household decision-making index, attitude towards violence index and lifetime experience of violence index.

\section{Variables measurement}

\section{Nutritional status of children measurement}

To provide answer to the question 'What is the extent of relationship between women's empowerment and children under-5 nutritional status in sub-Saharan African countries?',
Table 1 Survey characteristics

\begin{tabular}{|c|c|c|}
\hline Country & Survey year & $\mathrm{N}$ \\
\hline Benin & $2016-17$ & 5427 \\
\hline Burundi & $2016-17$ & 5600 \\
\hline Cameroon & 2011 & 4167 \\
\hline Chad & 2014-15 & 7910 \\
\hline Comoros & 2012 & 1971 \\
\hline Cote d'Ivoire & 2012 & 2225 \\
\hline Democratic Republic of Congo & 2013-14 & 6320 \\
\hline Ethiopia & 2016 & 8780 \\
\hline Gabon & 2012 & 1690 \\
\hline Gambia & 2013 & 2547 \\
\hline Ghana & 2014 & 2256 \\
\hline Guinea & 2012 & 2797 \\
\hline Kenya & 2014 & 6728 \\
\hline Lesotho & 2014 & 850 \\
\hline Liberia & 2013 & 1990 \\
\hline Malawi & $2015-16$ & 4246 \\
\hline Mali & 2013 & 4049 \\
\hline Mozambique & 2011 & 7591 \\
\hline Namibia & 2013 & 620 \\
\hline Niger & 2012 & 4752 \\
\hline Nigeria & 2013 & 22,669 \\
\hline Rwanda & 2014-15 & 2946 \\
\hline Senegal & 2011 & 2804 \\
\hline Sierra Leone & 2013 & 3386 \\
\hline South Africa & 2016 & 402 \\
\hline Tanzania & 2015-16 & 7198 \\
\hline Togo & 2013-14 & 2674 \\
\hline Uganda & 2016 & 3568 \\
\hline Zambia & 2013-14 & 8681 \\
\hline Zimbabwe & 2015 & 4432 \\
\hline Total & & 141,275 \\
\hline
\end{tabular}

dataset from 30 sub-Saharan countries with information on nutritional status of children were considered. Positive relationship is expected between women's empowerment and children nutritional status. Improvement in women's empowerment is expected to lead to well-being of children inform of reduction in their nutritional status. This involves height and weight measurement of children under-5; heightfor-age (HAZ) and weight-for-age (WAZ) were used to measure stunting and underweight respectively. Using WHO Child Growth Standards as the reference population, the indices encompassed z-scores of standard deviation (SD) units from the median of the reference population. HAZ reflects linear growth and chronic undernutrition in early childhood (stunting) while WAZ reflects both acute and chronic 
undernutrition (underweight). The -2 standard deviations from the reference population median represent the cut-off point for WAZ (underweight) and HAZ (stunting). Children having $\mathrm{z}$-scores greater than -2.00 were coded as not stunted/underweight, that is 0 , while children having $\mathrm{z}$ scores of less or equal to -2.00 were coded as stunted/ underweight, that is 1 .

\section{Women's empowerment measurement}

In this study, three quantitative variables (as evident from literature) represent women's empowerment: household decision-making index, attitude towards violence index and lifetime experience of violence index [31, 35]. Recent studies on nutritional status of children and women's empowerment used simple additive index [31, 35, 39]. To align with these studies, simple additive index was created for decision-making and attitudes towards violence variables. Regression models were fitted and other determinants of women's empowerment and children's nutritional statuses were controlled to estimate the influence of women's empowerment on child malnutrition. Further analysis explored the association with other factors.

\section{Other covariates}

Variables that were identified as covariates in previous studies on women's empowerment and child undernutrition were explored as potential risk factors, confounders or effect modifiers [31, 35, 40, 41]. The following variables were explored as covariates: household wealth (poorest, poorer, middle, richer, and richest), place of residence (rural/urban), region, child's age (months), child's sex (male/female), child's birth order (1st-2nd $=1$, 3rd-4th $=2, \quad 5$ th -6 th $=3, \quad>6$ th $=4)$, respondent's age (years), respondent's Body Mass Index (low BMI $=<$ $18.5 \mathrm{~kg} / \mathrm{m} 2)$, respondent's and respondent's husband's education (no education $=0$, primary $=1$, secondary $=2$, higher $=3$ ), respondent and husband's age differential (husband older $=0$; respondent same age or older $=1$ ), respondent and husband's education differential (women has less education $=0$; woman has more education $=1$ ) and age at first marriage (years).

\section{Ethical consideration}

Secondary data, Demographic and Health Survey (DHS) datasets were used. Before the surveys were carried out, ethical clearance was obtained from the ethical committees of the respective countries. In addition, before participation, informed consent was also obtained from the women. Moreover, all DHS are approved by ICF international and Institutional Review Board (IRB) to ensure that the protocols comply with the U.S. Department of Health and Human Services regulations for the protection of human subjects. The data from the surveys were completely anonymized.

\section{Data analysis}

The study used Demographic and Health Surveys from 30 sub-Saharan African countries to examine women's empowerment and nutritional status of children. The most recent survey conducted by each country was considered. Sampling weights were accounted for. Being national surveys, weights were applied because the response rates vary among the different population groups or secondary sampling units. The sampling weights or mathematical adjustments were also applied to the data to correct for under-sampling and oversampling. Data were examined at univariate, bivariate and multivariate levels. At univariate level of data analysis, frequency and percentage distributions of variables were employed to describe outcomes, exposures and other characteristics of respondents. At bivariate level, associations between outcomes, exposure (experience of violence) and other covariates were explored with the use of chi square tests. In addition, Ranksum and Kruskal Wallis tests were used to examine the association with employment exposures (attitude towards violence and decision-making). The test of correlation between variables revealed assumptions of multicollinearity were not violated. At multivariate level, regression model was employed. A regression model was fitted to investigate independent effect of women's empowerment on nutritional status of children after controlling for respondents' age, BMI and education, child's sex and age, household wealth and area of residence. In addition, the study considers similarity of the results by key demographic characteristics. Age is an important demographic variable. It can affect reproductive behaviour and other characteristics of respondents and that of their partners. Age of respondents may be related to characteristics such as education, BMI and child age. Therefore, further analyses involved interaction with age difference between respondents and interaction with age difference between partners while respondents' age, BMI and education, child's sex and age, household wealth and area of residence where adjusted.

\section{Results}

The women's empowerment and childhood nutritional status by country are presented in Table 2 . There were variations between countries in sub-Saharan Africa.

The frequency and percentage distribution of sociodemographic characteristics of respondents (women in their reproductive ages) were explored for outcome variables. As Table 3 revealed, about a quarter of the total respondents $(22.7 \%)$ and $(22.2 \%)$ belonged to poorest and poorer wealth index categories. Each of the other categories of wealth index had less than one-fifth of the total respondents (middle, 19.9\%, richer, $18.9 \%$ and 
Table 2 Women's empowerment and nutritional status by country

\begin{tabular}{|c|c|c|c|c|c|}
\hline Variables/ Country & $\begin{array}{l}\text { Stunted } \\
\text { Cases (\%) }\end{array}$ & $\begin{array}{l}\text { Underweight } \\
\text { Cases (\%) }\end{array}$ & $\begin{array}{l}\text { Involvement in decision- } \\
\text { making } \\
\text { (No) } \\
\text { Cases (\%) }\end{array}$ & $\begin{array}{l}\text { Attitude to violence (In } \\
\text { support) } \\
\text { Cases (\%) }\end{array}$ & $\begin{array}{l}\text { Experience of violence } \\
\text { (Yes) } \\
\text { Cases (\%) }\end{array}$ \\
\hline Benin & $1746(32.2 \%)$ & $926(17.1 \%)$ & $1589(29.3 \%)$ & 1785 (32.9\%) & $387(7.1 \%)$ \\
\hline Burundi & 3103 (55.4\%) & 1609 (28.7\%) & 809 (14.4\%) & $3366(60.1 \%)$ & $696(12.4 \%)$ \\
\hline Cameroon & 1347 (32.3\%) & $618(14.8 \%)$ & 1300 (31.2\%) & 1957 (47.0\%) & $287(6.9 \%)$ \\
\hline Chad & $3192(40.4 \%)$ & $2388(30.2 \%)$ & 3238 (40.9\%) & $6255(79.1 \%)$ & $2,576(32.6 \%)$ \\
\hline Comoros & $588(29.8 \%)$ & 304 (15.4\%) & 825 (41.9\%) & $827(42.0 \%)$ & $176(9.0 \%)$ \\
\hline Cote d'Ivoire & $639(28.7 \%)$ & $322(14.5 \%)$ & 982 (44.1\%) & $1140(51.3 \%)$ & $258(11.6 \%)$ \\
\hline $\begin{array}{l}\text { Democratic Republic of } \\
\text { Congo }\end{array}$ & $2720(43.0 \%)$ & $1422(22.5 \%)$ & $1671(26.4 \%)$ & 4847 (76.7\%) & 1089 (17.2\%) \\
\hline Ethiopia & $3350(38.2 \%)$ & $2056(23.4 \%)$ & 1045 (11.9\%) & $6027(68.7 \%)$ & $2327(26.5 \%)$ \\
\hline Gabon & $260(15.4 \%)$ & $88(5.2 \%)$ & 219 (13.0\%) & $938(55.5 \%)$ & $91(5.4 \%)$ \\
\hline Gambia & $623(24.5 \%)$ & $423(16.6 \%)$ & $422(16.6 \%)$ & $1651(64.8 \%)$ & $266(10.4 \%)$ \\
\hline Ghana & $397(17.6 \%)$ & $242(10.7 \%)$ & $185(8.2 \%)$ & 760 (33.7\%) & $138(6.1 \%)$ \\
\hline Guinea & 861 (30.8\%) & $501(17.9 \%)$ & $1149(41.1 \%)$ & $2634(94.2 \%)$ & $1272(45.5 \%)$ \\
\hline Kenya & $1720(25.6 \%)$ & 730 (10.9\%) & 802 (11.9\%) & $3100(46.1 \%)$ & $318(4.7 \%)$ \\
\hline Lesotho & $245(28.8 \%)$ & $81(9.6 \%)$ & $22(2.6 \%)$ & 297 (35.0\%) & $23(2.7 \%)$ \\
\hline Liberia & $602(30.2 \%)$ & $274(13.8 \%)$ & $1678.4 \%)$ & $933(46.9 \%)$ & $73(3.7 \%)$ \\
\hline Malawi & 1543 (36.3\%) & $468.8(11.0 \%)$ & $604(14.2 \%)$ & $658(15.5 \%)$ & $76(1.8 \%)$ \\
\hline Mali & 1573 (38.9\%) & 1028 (25.4\%) & $2965(73.2 \%)$ & $3229(79.7 \%)$ & 808 (20.0\%) \\
\hline Mozambique & $3226(42.5 \%)$ & 1137 (12.9\%) & 1046 (13.8\%) & 1785 (23.5\%) & $134(1.8 \%)$ \\
\hline Namibia & 123 (19.9\%) & $80(12.9)$ & $33(5.4 \%)$ & $208(33.5 \%)$ & $45(7.3 \%)$ \\
\hline Niger & 2041 (42.9\%) & $\begin{array}{l}1,716 \\
(36.1 \%)\end{array}$ & $2850(60.0 \%)$ & 2914 (61.3\%) & 1448 (30.5\%) \\
\hline Nigeria & $8427(37.2 \%)$ & 6604 (29.1\%) & 11,312 (49.9\%) & 8654 (38.2\%) & $2798(12.3 \%)$ \\
\hline Rwanda & 1084 (36.8\%) & $243(8.2 \%)$ & $210(7.1 \%)$ & 1187 (40.3\%) & $129(4.4 \%)$ \\
\hline Senegal & 773 (27.6\%) & 504 (18.0\%) & $1524(54.4 \%)$ & 1847 (65.9\%) & 626 (22.3\%) \\
\hline Sierra Leone & 1274 (37.6\%) & 538 (15.9\%) & 1082 (32.0\%) & 2446 (72.3\%) & 625 (18.4\%) \\
\hline South Africa & 101 (25.2\%) & $13(3.2 \%)$ & $10(2.6 \%)$ & $26(6.6)$ & $00(00.0 \%)$ \\
\hline Tanzania & 2437 (33.9\%) & 976 (13.6\%) & 1411 (19.6\%) & 4440 (61.7\%) & 1262 (17.5\%) \\
\hline Togo & $700(26.2 \%)$ & $412(15.4 \%)$ & 742 (27.7\%) & 875 (32.7\%) & 166 (6.2\%) \\
\hline Uganda & 1007 (28.2\%) & 349 (9.8\%) & $520(14.6 \%)$ & 1757 (49.2\%) & $211(5.9 \%)$ \\
\hline Zambia & 3463 (39.9\%) & 1239 (14.3\%) & 1118 (12.9\%) & 4.452 (51.3\%) & 1515 (17.5\%) \\
\hline Zimbabwe & 1127 (25.4\%) & 334 (7.5\%) & 170 (3.8\%) & 1734 (39.1\%) & $192(4.3 \%)$ \\
\hline Total & $\begin{array}{l}50,291 \\
(35.6 \%)\end{array}$ & $\begin{array}{l}27,623 \\
(19.6 \%)\end{array}$ & 40,025 (28.3\%) & 72,730 (51.5\%) & $20,012(14.2 \%)$ \\
\hline
\end{tabular}

richest, $16.3 \%)$. Majority of the respondents $(71.8 \%$ versus $28.2 \%$ ) indicated they resided in rural areas. The age distributions of children were about one-fifth for each age category and sex distributions of children were also about the same (male, 50.1\% versus female, $49.9 \%$ ). The percentage distribution of birth order followed a descending pattern, the higher the percentage, the lower the birth order. By age distribution of respondents, it followed an ascending order on till 30-34 age group while descending pattern started from 35 to 39 age group and continued till 45-49 age group. Respondents without low BMI constituted $90.7 \%$ of the total respondents while $9.3 \%$ reported low BMI. Distribution by educational attainment revealed a descending pattern $42.2 \%$ had no formal education, $34.7 \%$ had primary education, $20.0 \%$ had secondary education and $3.1 \%$ had higher level of education.

Percentage distribution by age differential showed that $37.4 \%$ of respondents were more than eight years younger than their husbands while $37.9 \%$ indicated they were 
Table 3 Relationship between outcomes and Exposures with Covariates

\begin{tabular}{|c|c|c|c|c|c|c|c|c|c|}
\hline \multirow{2}{*}{$\begin{array}{l}\text { Covariates } \\
\text { Variable }\end{array}$} & \multirow[b]{2}{*}{ Category } & \multirow[b]{2}{*}{$\begin{array}{l}\text { Frequency } \\
(\%)\end{array}$} & \multicolumn{2}{|l|}{ Stunted } & \multicolumn{2}{|c|}{ Underweight } & \multirow{2}{*}{$\begin{array}{l}\begin{array}{l}\text { Decision- } \\
\text { making }\end{array} \\
\text { Rank sum/K } \\
\text { Wallis } p \text {-valu }\end{array}$} & \multirow{2}{*}{$\begin{array}{l}\text { Violence } \\
\text { Attitudes }\end{array}$} & \multirow{2}{*}{$\begin{array}{l}\begin{array}{l}\text { Experience o } \\
\text { violence }\end{array} \\
\text { Chi-2 } p \text {-value }\end{array}$} \\
\hline & & & $\begin{array}{l}\text { Chi-2 } p \text { - } \\
\text { value }\end{array}$ & $\begin{array}{l}\text { Cases } \\
(\%)\end{array}$ & $\begin{array}{l}\text { Chi-2 } p- \\
\text { value }\end{array}$ & $\begin{array}{l}\text { Cases } \\
(\%)\end{array}$ & & & \\
\hline \multirow[t]{6}{*}{ Wealth Index } & Poorest & $\begin{array}{l}32,073 \\
(22.7)\end{array}$ & $<0.001$ & $\begin{array}{l}14,213 \\
(44.3)\end{array}$ & $<0.001$ & $\begin{array}{l}8363 \\
(26.1)\end{array}$ & $<0.001$ & $<0.001$ & $<0.001$ \\
\hline & Poorer & $\begin{array}{l}31,291 \\
(22.2)\end{array}$ & & $\begin{array}{l}12,861 \\
(41.1)\end{array}$ & & $\begin{array}{l}7095 \\
(22.7)\end{array}$ & & & \\
\hline & Middle & $\begin{array}{l}28,160 \\
(19.9)\end{array}$ & & $\begin{array}{l}10,256 \\
(36.4)\end{array}$ & & $\begin{array}{l}5292 \\
(18.8)\end{array}$ & & & \\
\hline & Richer & $\begin{array}{l}26,679 \\
(18.9)\end{array}$ & & $\begin{array}{l}8284 \\
(31.1)\end{array}$ & & $\begin{array}{l}4364 \\
(16.4)\end{array}$ & & & \\
\hline & Richest & $\begin{array}{l}23,072 \\
(16.3)\end{array}$ & & $\begin{array}{l}4677 \\
(20.3)\end{array}$ & & $\begin{array}{l}2509 \\
(10.9)\end{array}$ & & & \\
\hline & Total & $\begin{array}{l}141,275 \\
(100)\end{array}$ & & $\begin{array}{l}50,291 \\
(35.6)\end{array}$ & & $\begin{array}{l}27,623 \\
(19.6)\end{array}$ & & & \\
\hline \multirow[t]{3}{*}{ Type of Residence } & Urban & $\begin{array}{l}39,889 \\
(28.2)\end{array}$ & $<0.001$ & $\begin{array}{l}9988 \\
(25.0)\end{array}$ & $<0.001$ & $\begin{array}{l}5405 \\
(13.6)\end{array}$ & $<0.001$ & $<0.001$ & $<0.001$ \\
\hline & Rural & $\begin{array}{l}101,386 \\
(71.8)\end{array}$ & & $\begin{array}{l}40,303 \\
(39.8)\end{array}$ & & $\begin{array}{l}22,218 \\
(21.9)\end{array}$ & & & \\
\hline & Total & $\begin{array}{l}141,275 \\
(100)\end{array}$ & & $\begin{array}{l}50,291 \\
(35.6)\end{array}$ & & $\begin{array}{l}27,623 \\
(19.6)\end{array}$ & & & \\
\hline \multirow[t]{6}{*}{ Child age } & $<1$ year & $\begin{array}{l}30,188 \\
(21.4)\end{array}$ & $<0.001$ & $\begin{array}{l}5518 \\
(18.3)\end{array}$ & $<0.001$ & $\begin{array}{l}4417 \\
(14.6)\end{array}$ & $<0.001$ & 0.822 & 0.180 \\
\hline & 1 & $\begin{array}{l}29,238 \\
(20.7)\end{array}$ & & $\begin{array}{l}11,222 \\
(38.4)\end{array}$ & & $\begin{array}{l}6110 \\
(20.9)\end{array}$ & & & \\
\hline & 2 & $\begin{array}{l}27,362 \\
(19.4)\end{array}$ & & $\begin{array}{l}12,274 \\
(44.9)\end{array}$ & & $\begin{array}{l}5926 \\
(21.7)\end{array}$ & & & \\
\hline & 3 & $\begin{array}{l}27,736 \\
(19.6)\end{array}$ & & $\begin{array}{l}11,561 \\
(41.7)\end{array}$ & & $\begin{array}{l}5695 \\
(20.5)\end{array}$ & & & \\
\hline & 4 & $\begin{array}{l}26,752 \\
(18.9)\end{array}$ & & $\begin{array}{l}9716 \\
(36.3)\end{array}$ & & $\begin{array}{l}5476 \\
(20.5)\end{array}$ & & & \\
\hline & Total & $\begin{array}{l}141,275 \\
(100)\end{array}$ & & $\begin{array}{l}50,291 \\
(35.6)\end{array}$ & & $\begin{array}{l}27,623 \\
(19.6)\end{array}$ & & & \\
\hline \multirow[t]{3}{*}{ Sex of Child } & Male & $\begin{array}{l}70,839 \\
(50.1)\end{array}$ & $<0.001$ & $\begin{array}{l}26,709 \\
(37.7)\end{array}$ & $<0.001$ & $\begin{array}{l}14,658 \\
(20.7)\end{array}$ & 0.601 & 1.000 & 0.859 \\
\hline & Female & $\begin{array}{l}70,436 \\
(49.9)\end{array}$ & & $\begin{array}{l}23,582 \\
(33.5)\end{array}$ & & $\begin{array}{l}12,965 \\
(18.4)\end{array}$ & & & \\
\hline & Total & $\begin{array}{l}141,275 \\
(100)\end{array}$ & & $\begin{array}{l}50,291 \\
(35.6)\end{array}$ & & $\begin{array}{l}27,623 \\
(19.6)\end{array}$ & & & \\
\hline \multirow[t]{5}{*}{ Birth order } & 1st-2nd & $\begin{array}{l}51,827 \\
(36.7)\end{array}$ & $<0.001$ & $\begin{array}{l}17,402 \\
(33.6)\end{array}$ & $<0.001$ & $\begin{array}{l}8871 \\
(17.1)\end{array}$ & $<0.001$ & $<0.001$ & $<0.001$ \\
\hline & $3 r d-4$ th & $\begin{array}{l}42,151 \\
(29.8)\end{array}$ & & $\begin{array}{l}14,651 \\
(34.8)\end{array}$ & & $\begin{array}{l}7958 \\
(18.9)\end{array}$ & & & \\
\hline & 5th-6th & $\begin{array}{l}26,607 \\
(18.8)\end{array}$ & & $\begin{array}{l}10,059 \\
(37.8)\end{array}$ & & $\begin{array}{l}5727 \\
(21.5)\end{array}$ & & & \\
\hline & $\begin{array}{l}\text { More than } \\
6 \text { th }\end{array}$ & $\begin{array}{l}20,691 \\
(14.7)\end{array}$ & & $\begin{array}{l}8180 \\
(39.5)\end{array}$ & & $\begin{array}{l}5067 \\
(24.5)\end{array}$ & & & \\
\hline & Total & $\begin{array}{l}141,275 \\
(100)\end{array}$ & & $\begin{array}{l}50,291 \\
(35.6)\end{array}$ & & $\begin{array}{l}27,623 \\
(19.6)\end{array}$ & & & \\
\hline \multirow[t]{3}{*}{ Respondents' age } & $15-19$ & $6541(4.6)$ & $<0.001$ & $\begin{array}{l}2419 \\
(37.0)\end{array}$ & $<0.001$ & $\begin{array}{l}1368 \\
(20.9)\end{array}$ & $<0.001$ & $<0.001$ & $<0.001$ \\
\hline & $20-24$ & $\begin{array}{l}28,864 \\
(20.4)\end{array}$ & & $\begin{array}{l}10,739 \\
(37.2)\end{array}$ & & $\begin{array}{l}5562 \\
(19.3)\end{array}$ & & & \\
\hline & $25-29$ & 39,985 & & 14,028 & & 7610 & & & \\
\hline
\end{tabular}


Table 3 Relationship between outcomes and Exposures with Covariates (Continued)

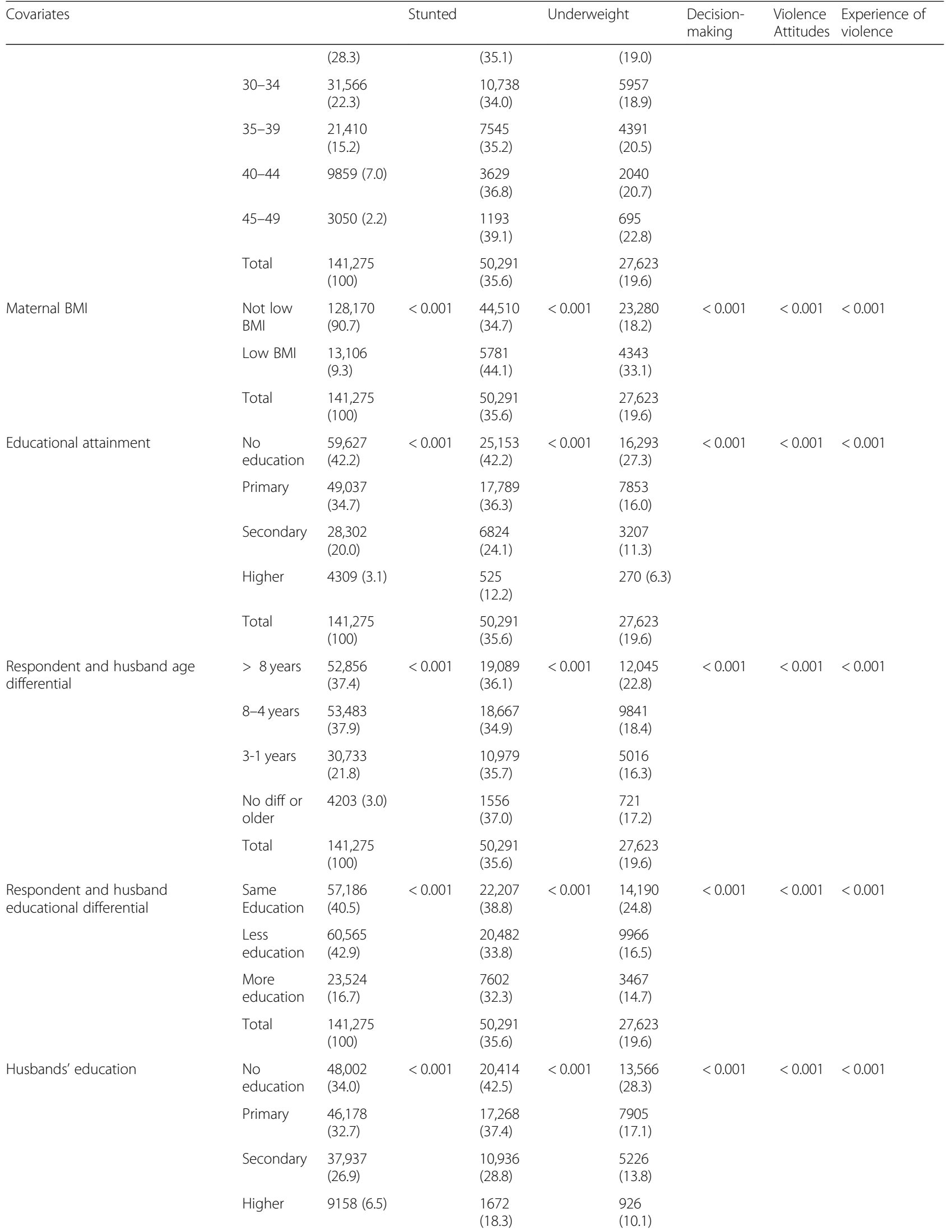


Table 3 Relationship between outcomes and Exposures with Covariates (Continued)

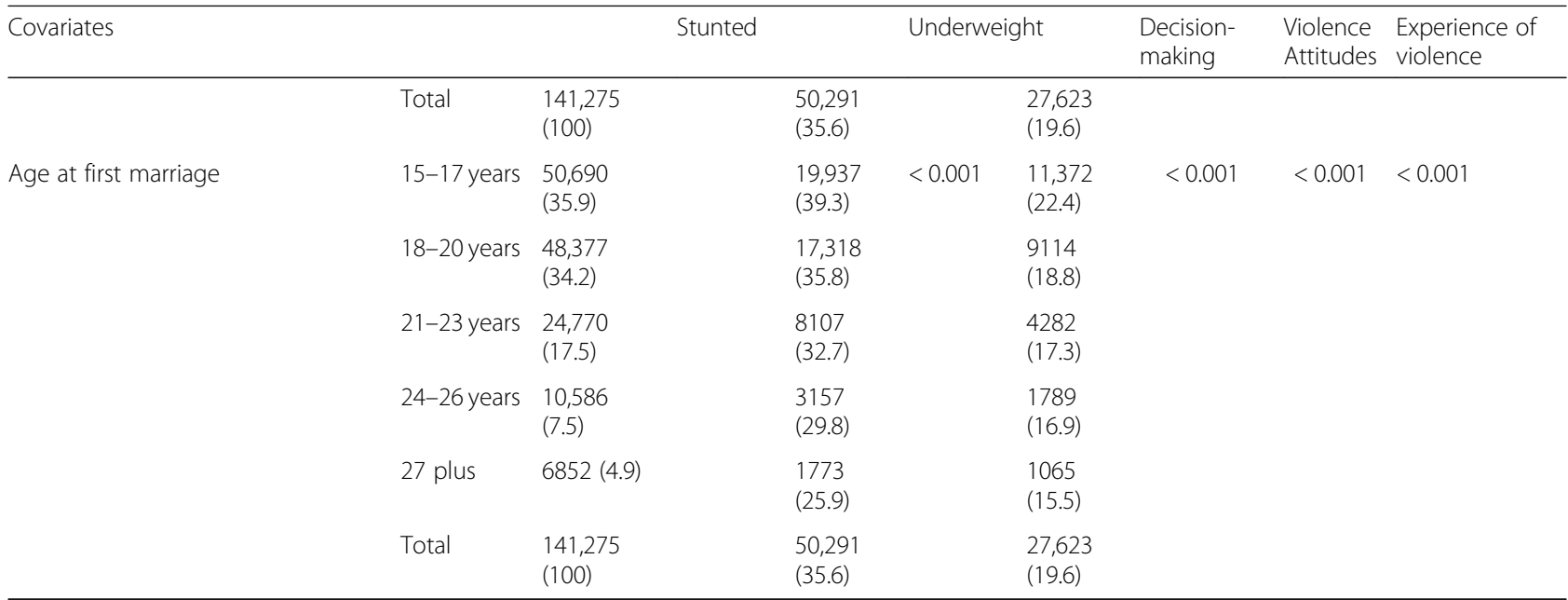

eight to four years younger than their husbands. In addition, those who were three to one year younger than their husbands were $21.8 \%$, those who indicated no age difference or older than their husband were less than $5 \%$ (3.0\%). Distribution by educational difference revealed $40.5 \%$ had the same education, $42.9 \%$ less educated than their husband and $16.7 \%$ more educated than their husbands. More than one-third (35.9\%) of the respondents married at $15-17$ years age range and also more than one-third (34.2\%) married at 18-20 years age range while $29.9 \%$ married at later ages.

As indicated in Table 3, all the socio-demographic and other selected characteristics of respondents were statistically significantly associated with childhood nutritional status (stunted and underweight) at $p<0.001$. These characteristics were also statistically significantly associated with empowerment status of women (Decision-making, Violence attitudes and Experience of violence) at $\mathrm{p}<0.001$ except for child age and sex (see Table 2). Table 4 revealed correlation among the covariates. The correlation between covariates was less than 0.7. Moreover, correlation between main exposure variables was less than 0.13 except between attitudes towards violence and experience of violence which was 0.72 , therefore, the two variables were not considered in the same analysis (Table 5).

Results from Table 6 revealed the result of multivariate analyses. The association between childhood nutritional statuses and women's empowerment (all three empowerment measures) was significant after controlling for other covariates that could also influence childhood nutrition statuses. Two of the empowerment measures (attitudes towards violence and experience of violence) showed positive association with childhood nutritional statuses while the third (decision-making) showed negative association. The study showed the existence of independent relationship between childhood nutrition statuses and women's empowerment in sub Saharan African countries. However, the association did not imply causality. This study cannot assert causality because the data used were cross-sectional. In addition, the association between

Table 4 Correlation between Covariates

\begin{tabular}{|c|c|c|c|c|c|c|c|}
\hline Correlation ( $p$-value) & Respondents' age & Respondents' education & $\begin{array}{l}\text { Maternal } \\
\text { BMl }\end{array}$ & Child age & Husband's education & Age differential & Wealth \\
\hline Respondents' age & 1.0000 & & & & & & \\
\hline Respondents' education & $-0.1003(<0.001)$ & 1.0000 & & & & & \\
\hline $\begin{array}{l}\text { Maternal } \\
\text { BMI }\end{array}$ & $\begin{array}{l}0.0317 \\
(0.0000)\end{array}$ & $0.1126(<0.001)$ & 1.0000 & & & & \\
\hline Child age & $\begin{array}{l}0.1801 \\
(<0.001)\end{array}$ & $\begin{array}{l}-0.0422 \\
(<0.001)\end{array}$ & $\begin{array}{l}0.0084 \\
(0.002)\end{array}$ & 1.0000 & & & \\
\hline Husband's education & $\begin{array}{l}-0.0686 \\
(<0.001)\end{array}$ & $0.6465(<0.001)$ & $0.1107(<0.001)$ & $\begin{array}{l}-0.0312 \\
(<0.001)\end{array}$ & 1.0000 & & \\
\hline Age differential & $\begin{array}{l}0.0377 \\
(<0.001)\end{array}$ & $0.1445(<0.001)$ & $0.0263(<0.001)$ & $\begin{array}{l}-0.0115 \\
(<0.001)\end{array}$ & $0.1338(<0.001)$ & 1.0000 & \\
\hline Wealth & $\begin{array}{l}0.0103 \\
(<0.001)\end{array}$ & $0.4107(<0.001)$ & $\begin{array}{l}0.1071 \\
(<0.001)\end{array}$ & $\begin{array}{l}0.0001 \\
(<0.9672)\end{array}$ & $0.3879(<0.001)$ & $0.0103(<0.001)$ & 1.0000 \\
\hline
\end{tabular}


Table $\mathbf{5}$ Correlation between Main Exposure Variables

\begin{tabular}{llll}
\hline $\begin{array}{l}\text { Correlation } \\
(p \text {-value })\end{array}$ & $\begin{array}{l}\text { Decision- } \\
\text { making }\end{array}$ & $\begin{array}{l}\text { Attitudes towards } \\
\text { violence }\end{array}$ & $\begin{array}{l}\text { Experience of } \\
\text { violence }\end{array}$ \\
\hline Decision-making & 1.0000 & & \\
$\begin{array}{l}\text { Attitudes towards } \\
\text { violence }\end{array}$ & $\begin{array}{l}-0.1701(< \\
0.001)\end{array}$ & 1.0000 & \\
$\begin{array}{l}\text { Experience of } \\
\text { violence }\end{array}$ & $\begin{array}{l}-0.1248(< \\
0.001)\end{array}$ & $0.7182(<0.001)$ & 1.0000 \\
\hline
\end{tabular}

childhood nutritional statuses and women's empowerment was also examined with age of respondents and age difference between partners as interactive factors. The results revealed large variability. However, it can be established that women's empowerment was associated with childhood nutritional statuses due to evident of statistically significant relationship.

\section{Discussion and policy implications}

The study reported more respondents in the poorest and poorer wealth index categories compared to richer and richest categories. Income has been found to be associated with women's empowerment. Having more of the respondents in the poorest and poorer wealth index categories was a pointer to low women's self-esteem and therefore low women's empowerment [13, 25, 26]. This corroborated Kabeer's theory on empowerment and poverty. Inability of people to exercise choice may result due to limited resources. She associated poverty with low women's empowerment [32]. Wealth index as a factor was found to be associated with women's empowerment. This had semblance with the fact that majority of the respondents also lived in rural areas. About half of them had no formal education and more than seven in ten married before age 20. Low level of education and early marriage may also lead to low self-esteem which may subsequently hamper women's empowerment $[13,25,26]$. It was also noted that the same proportion of respondents had less than one, one, two, three- and four-years old children. These were not their completed fertility. In addition, sex distribution followed similar pattern with male and female having about the same proportion. Birth order of respondents revealed those with one to two children had the highest proportion while lowest proportion was from respondents with six or more children.

It should be noted that many of the respondents with one to two children would have more children because they had not attained their completed fertility. More than one-third of respondents belonged to 20-34 age range while about one-tenth of the total respondents had low BMI. Very few women (respondents) reported that they were of equal age or older than their husbands while about 2 in 5 had the same education or less educated compared to their husbands. Moreover, altogether, about six in ten women (respondents) were less educated than their husbands. Women's education enhances women's empowerment and their participation in decision-making [13, 22-24]. Disparity and low educational attainment on the part of women may influence their participation in decision-making and empowerment.

The study reported disparity in childhood nutritional status by socio-demographic characteristics. This might not be unconnected with disparities in educational attainment, place of residence and other factors. Though, these socio-demographic variables were related to childhood nutritional status [22-24, 31]. Women BMI was found to be significantly associated with nutritional status of their children. Indeed, the well-being of mothers may translate or reflect in the well-being of their children. Empowered women may have more potential to meet the needs of their children compared to their counterparts. Moreover, the distribution of women's empowerment measures showed inequalities across socio-demographic and other selected characteristics. Significant associations were observed between women's empowerment measures and socio-demographic and other selected characteristics except for age and sex of children. Multivariate regression model fitted to investigate independent effect of women's empowerment measures on nutritional status of children

Table 6 Fully adjusted Model and Model with Interaction

\begin{tabular}{|c|c|c|c|c|c|c|c|c|c|c|}
\hline \multirow{3}{*}{ Variable } & \multirow{3}{*}{ Category/unit } & \multicolumn{3}{|c|}{ Full adjustment* } & \multicolumn{6}{|c|}{ Interaction with age difference between partners } \\
\hline & & \multicolumn{3}{|c|}{ Stunting } & \multicolumn{3}{|c|}{$\begin{array}{l}\text { Respondent younger than husband or no } \\
\text { difference }\end{array}$} & \multicolumn{3}{|c|}{$\begin{array}{l}\text { Respondent older than } \\
\text { husband }\end{array}$} \\
\hline & & OR & $95 \% \mathrm{Cl}$ & $p$-value & OR & $95 \% \mathrm{Cl}$ & $p$-value & OR & $95 \% \mathrm{Cl}$ & $p$-value \\
\hline Decision-making & & 0.84 & $\begin{array}{l}0.83 \\
0.86\end{array}$ & 0.001 & 0.88 & $\begin{array}{l}0.77 \\
1.01\end{array}$ & 0.08 & 1.13 & $\begin{array}{l}0.99 \\
1.30\end{array}$ & 0.08 \\
\hline \multirow[t]{2}{*}{ Any Experience of violence } & & 1.07 & $1.04,1.11$ & 0.001 & 0.91 & $\begin{array}{l}0.74 \\
1.12\end{array}$ & 0.34 & 1.10 & $\begin{array}{l}0.89 \\
1.36\end{array}$ & 0.38 \\
\hline & & & & & \multicolumn{6}{|c|}{ Interaction with Age of Respondent } \\
\hline Variable & Category/unit & \multicolumn{3}{|c|}{ Underweight } & \multicolumn{3}{|c|}{ Respondent Age 15-29 } & \multicolumn{3}{|c|}{ Respondent Age 30-49 } \\
\hline Attitude towards violence & & 1.13 & $\begin{array}{l}1.10 \\
1.16\end{array}$ & 0.001 & 0.98 & $\begin{array}{l}0.93 \\
1.04\end{array}$ & 0.52 & 1.02 & $\begin{array}{l}0.96 \\
1.08\end{array}$ & 0.52 \\
\hline
\end{tabular}

*Adjusted for respondents' age, BMI and education, child's sex and age, household wealth and area of residence 
revealed women's empowerment was independently related to childhood nutritional status. Findings from this study were consistent with the previous studies that have shown a relationship between women empowerment and child health outcomes [31, 42]. The results from this study suggest that women's empowerment is an incredibly complex issue, and that childhood welfare and nutritional status are linked to the degree of autonomy the woman has in effecting change in her household.

Childhood malnutrition affects in sub-Saharan Africa affects more than 1 in 3 children and although child nutritional stats have improved over the past several decades, countries continue to struggle in the fight against malnutrition [40]. The Sustainable Development Goals (SDGs) aim to end hunger, achieve food security, improve nutrition especially among children and the most vulnerable by 2030. This study thus shows that in order to achieve nutrition justice, women's status in terms of the three dimensions (household decision-making index, attitude towards violence index and lifetime experience of violence index) should be taken into consideration in interventions by policymakers as well as international bodies. These interventions should be gender-responsive so to help transform norms, stereotypes and attitudes that uphold female subordination,

\section{Strengths and limitations}

The datasets are not only from many countries but also nationally representative. In fact, the sample size collected from these rounds of surveys was sufficiently large and by standard procedure which increases the external validity of the findings for women aged between 15 to 49 years in Sub-Saharan Africa. However, there are also limitations to the study. Other studies [43-45] for instance have shown that religion is associated with women's empowerment and that "any meaningful effort to promote women empowerment in Africa must account for the continent's three main religions" [43]. However, religion as a variable was not considered in our study because information on religion is not representative due to a lot of missing values in the dataset. In addition, the surveys used crosssectional design which only permits associations but not causalities. Moreover, DHS surveys were conducted in different years, comparison of results from different surveys should be done with caution $[46,47]$.

\section{Conclusion}

The study explored the association between women's empowerment and childhood nutritional status in sub Saharan African countries. Despite the efforts at reducing childhood malnutrition statuses, the persistent burden of malnutrition among children threatens the health and future development in the region and also the achievement of Sustainable Development Goals for child and maternal health. To reduce childhood malnutrition and prevent the associated ill-health, risk factor such as women's empowerment needs to be addressed. Necessary policies, programmes and interventions channelled towards women's empowerment could help to reduce childhood malnutrition. Moreover, childhood malnutrition could be addressed at the population and individual levels taking cognizance of the factors associated with women's empowerment.

\section{Acknowledgments}

The authors acknowledge the MEASURE DHS project for their support and for free access to the original data.

\section{Authors' contributions}

SY contributed to the study design, the review of literature analysis, manuscript conceptualisation and preparation. KEO OAU and GB reviewed the manuscript for its intellectual content and contributed to data analysis as well. All authors read and approved the final manuscript. SY had final responsibility to submit for publication. All authors read and approved the final manuscript.

\section{Funding}

The authors have no funding or support to report.

\section{Availability of data and materials}

Data for this study were from Demographic and Health surveys (DHS) and available here: http://dhsprogram.com/data/available-datasets.cfm.

Ethics approval and consent to participate

Ethics approval for this study was not required since the data is secondary and is available in the public domain. More details regarding DHS data and ethical standards are available at: http://goo.gl/ny8T6X.

\section{Consent for publication}

Not Applicable.

\section{Competing interests}

The authors have no competing interests.

\section{Author details}

${ }^{1}$ School of International Development and Global Studies, University of Ottawa, 120, University Private, Ottawa, ON K1N 6N5, Canada. ${ }^{2}$ The George Institute for Global Health, The University of Oxford, Oxford, UK.

${ }^{3}$ 2Department of Demography and Social Statistics, Federal University, Oye, Ekiti, Nigeria. ${ }^{4}$ Warwick Centre for Applied Health Research and Delivery (WCAHRD), Division of Health Sciences, Warwick Medical School, University of Warwick, Coventry CV4 7AL, UK.

Received: 8 July 2019 Accepted: 2 December 2019

Published online: 14 January 2020

\section{References}

1. Black RE, Victora CG, Walker SP, et al. Maternal and child undernutrition and overweight in low-income and middle-income countries. Lancet. 2013;382:427-51.

2. Cunningham $K$, Ruel M, Ferguson $E$, Uauy R. Women's empowerment and child nutritional status in South Asia: a synthesis of the literature. Maternal and Child Nutrition. 2015;11:1-19.

3. Na M, Jennings L, Talegawkar SA, Ahmed S. Association between women's empowerment and infant and child feeding practices in sub-Saharan Africa: an analysis of demographic and health surveys. Public Health Nutr. 2015; 18(17):3155-65. https://doi.org/10.1017/S1368980015002621.

4. Hoffman D, Cacciola T. Barrios1 P, Simon J. temporal changes and determinants of childhood nutritional status in Kenya and Zambia. Journal of health, population and. Nutrition. 2017;36:27.

5. Akombi BJ, Agho KE, Merom D, Renzaho AM Hall JJ. Child malnutrition in sub-Saharan Africa: a meta-analysis of demographic and health surveys (2006-2016). PLoS One 2017 Nov 5; 12(5): p1-11. 11p. 
6. Beiersmann C, Bermejo Lorenzo J, Bountogo M, Tiendrébeogo J, Gabrysch S, Yé M, Jahn A, Müller O. Malnutrition determinants in young children from Burkina Faso. J Trop Pediatr 2013 Oct; 59 (5): p372-379. 8p.

7. Tonguet-Papucci1 A, Huybregts L, Aissa MA, Huneau J, Kolsteren P. The MAM'Out project: a randomized controlled trial to assess multiannual and seasonal cash transfers for the prevention of acute malnutrition in children under 36 months in Burkina Faso. BMC Public Health. 2015; 15:762.

8. Rabaoarisoa CR, Rakotoarison R, Rakotonirainy NH, Mangahasimbola RT, Randrianarisoa $A B$, Jambou $R$. The importance of public health, poverty reduction programs and women's empowerment in the reduction of child stunting in rural areas of Moramanga and Morondava. Madagascar PLoS ONE. 2017;12(10):e0186493 https://doi.org/10.1371/.

9. de Onis M, Dewey KG, Borghi E, Onyango AW, Blossner M, Daelmans B, et al. The World Health Organization's global target for reducing childhood stunting by 2025 : rationale and proposed actions. Matern Child Nutr. 2013;9(Suppl 2):6-26.

10. Olack B, Burke H, Cosmas L, Bamrah S, Dooling K, Feikin DR, Talley LE, Breiman RF. Nutritional status of under-five children living in an informal urban settlement in Nairobi, Kenya. J Health Popul Nutr. 2011 Aug; 29(4): 357-363 ISSN 1606-0997.

11. Bhutta ZA, Das JK, Rizvi A, Gaffey MF, Walker N, Horton S, et al. Evidence based interventions for improvement of maternal and child nutrition: what can be done and at what cost? Lancet. 2013;382(9890):452-77.

12. Kalu RE, Etim, KD. Factors associated with malnutrition among underfive children in developing countries: a review. Global Journal of Pure \& Applied Sciences 2018; 24(1): p69-74. 6p.

13. Imai KS, Annim SK, Kulkarni VS, Gaiha ER. Women's empowerment and prevalence of stunted and underweight children in rural India. World Dev. 2014;62:88-105 https://doi.org/10.1016/j.worlddev.2014.05.001.

14. Haas JD, Martinez EJ, Murdoch S, Conlisk E, Rivera JA, Martorell R. Nutritional supplementation during the preschool years and physical work capacity in adolescent and young adult Guatemalans. J Nutr. 1995;125(4 Suppl):1078S89S.

15. Victora CG, Adair L, Fall C, Hallal PC, Martorell R, Richter L, et al. Maternal and child undernutrition: consequences for adult health and human capital. Lancet. 2008;371(9609):340-57.

16. Dewey KG, Begum K. Long-term consequences of stunting in early life. Matern Child Nutr. 2011;7(3 Suppl):5-18

17. Kamiya Y, Nomura M, Ogino H, Yoshikawa K, Siengsounthone L, Xangsayarath P. Mothers' autonomy and childhood stunting: evidence from semi-urban communities in Lao PDR. BMC Womens Health. 2018;18:70. https://doi.org/10.1186/s12905-018-0567-3.

18. Berkman DS, Lescano AG, Gilman RH, Lopez SL, Black MM. Effects of stunting, diarrhoeal disease, and parasitic infection during infancy on cognition in late childhood: a follow-up study. Lancet. 2002;359:564-71. https://doi.org/10.1016/S0140-6736(02)07744-9.

19. Black RE, Allen LH, Bhutta ZA, Caulfield LE, de Onis M, Ezzati M, et al. Maternal and child undernutrition: global and regional exposures and health consequences. Lancet. 2008; 371: 243土260. https:/doi.org/10.1016/S0140-6736(07)61690-0.

20. Hoddinott J, Maluccio JA, Behrman JR, Flores R, Martorell R. Effect of a nutrition intervention during early childhood on economic productivity in Guatemalan

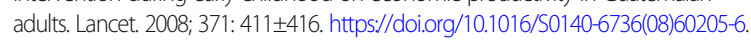

21. Victora CG, Adair L, Fall C, Hallal PC, Martorell R, Richter L, et al. Maternal and child undernutrition: consequences for adult health and human capital. Lancet. 2008;371:340-57. https://doi.org/10.1016/S0140-6736(07)61692-4.

22. Ackerson LK, Subramanian SV. Domestic violence and chronic malnutrition among women and children in India. Am J Epidemiol. 2008;167(10):1188-96.

23. Allendorf K. Do women's land rights promote empowerment and child health in Nepal? World Dev. 2007;35(11):1975-88.

24. Kandpal E, McNamara PE. Determinants of nutritional outcomes of children in India: A quantile regression approach. In Conference proceeding: The agricultural and applied economics association. AAEA \& ACCI joint annual meeting. Milwaukee, Wisconsin: AAEA \& ACCl; 2009.

25. Duflo E. Women empowerment and economic development. J Econ Lit. 2012;50(4):1051-79.

26. Luke $\mathrm{N}, \mathrm{Xu} \mathrm{H}$. Exploring the meaning of context for health: community influences on child health in South India. Demogr Res. 2011;24:345-74.

27. Carlson GJ, Kordas K, Murray-Kolb LE. Associations between women's autonomy and child nutritional status: a review of literature. Matern Child Nutr. 2015 Oct;11(4):452-82. https://doi.org/10.1111/mcn.12113.

28. Pratley P. Associations between quantitative measures of Women's empowerment and access to care and health status for mothers and their children: a systematic review of evidence from the developing world. Social Science Medicine. 2016;169(1):119-31.

29. Beiersmann C, Bermejo Lorenzo J, Bountogo M, Tiendrébeogo J Gabrysch, S, Yé M, Jahn A, Müller, O. Malnutrition determinants in young children from Burkina Faso. J Trop Pediatr 2013 Oct; 59(5), p372-379. 8p.

30. Burroway R. Are all jobs created equal? A cross-national analysis of women's employment and child malnutrition in developing countries. Soc Sci Res 2017 Sep. 67, p1-13. 13p.

31. Scantlan J, Previdelli A. Women's empowerment and childhood malnutrition in Timor-Leste: a mixed-methods study. Mercy Corps: Portland, Oregon; 2013.

32. Kabeer N. Resources, agency, achievements: reflections on the measurement of women's empowerment. Dev Chang. 1999;30(May):435-64.

33. Malhotra A, Schuler SR, Boender C. Measuring Women's empowerment as a variable in international development. Washington D.C., 2002.

34. Amartya S. Commodities and capabilities. Amsterdam New York New York, N.Y., U.S.A: North-Holland, 1985

35. Bhagowalia P, Quisumbing AR. What dimensions of women's empowerment matter most for child nutrition? Evidence using nationally representative data from Bangladesh, Washington D.C., 2012. Retrieved from http://www.ifpri.org/publication/ what-dimensions-women-s-empowerment-matter-most-child-nutrition.

36. Samman E, Santos ME. Agency and empowerment: A review of concepts, indicators and empirical evidence. Retrieved from http//wwww.ophi.org.uk/ophi-research-paper-10a/.

37. Short Fabic M, Choi Y, Bird S. A systematic review of demographic and health surveys: data availability and utilization for research. Bull World Health Organ. 2012 Aug 1;90(8):604-12.

38. Corsi DJ, Neuman M, Finlay JE, Subramanian S. Demographic and health surveys: a profile. Int J Epidemiol. 2012 Dec 1;41(6):1602-13.

39. Allendorf K. Do women's land rights promote empowerment and child health in Nepal? World Dev. 2007;35(11):1975-88.

40. Smith LC, Ramakrishnan U, Ndiaye A, Haddad L. Martorell R. Rica C. The importance of women's status for child nutrition in developing countries: Mayufis RG; 2003. Retrieved from http://www.ifpri.org/publication/ importance-womens-status-child-nutrition-developing-countries

41. Desai S, Johnson K. Women's decision-making and child health: familial and social hierarchies. In: Kishor S, editor. A focus on gender: collected papers on gender using DHS data. Calverton: ORC Macro; 2005. p. 55-68. Retrieved from http://www.measuredhs.com/pubs/pdf/OD32/00FrontMatter00.pdf.

42. Duflo E. Women's empowerment and economic development. J Econ Lit. 2012;50(4):1051-79.

43. Njoh JA, Akiwumi FA. The impact of religion on women empowerment as a millennium development goal in Africa. Soc Indic Res. 2012;107:1. https:// doi.org/10.1007/s11205-011-9827-4.

44. Seguino S. Help or hindrance? Religion's impact on gender inequality in attitudes and outcomes. World Dev. 2011;39(8):1308-21.

45. Agadjanian V, Yabiku ST. Religious belonging, religious agency, and women's autonomy in Mozambique. J Sci Study Relig. 2015;54(3):461-76.

46. Yaya S, Buh A, Bishwajit G. Satisfaction with job and family life, and association with smoking and alcohol drinking behaviors among young men in Malawi: analysis from a multiple indicator survey. 2019; BMC research notes 12 (1), 57, https://doi.org/10.1186/s13104-019-4096-4.

47. Yaya S, Bishwajit G. Trend in overweight and obesity among women of reproductive age in Uganda: 1995-2016. Obes Sci Pract. 2019;5(4):312-23. https://doi.org/10.1002/osp4.351.

\section{Ready to submit your research? Choose BMC and benefit from:}

- fast, convenient online submission

- thorough peer review by experienced researchers in your field

- rapid publication on acceptance

- support for research data, including large and complex data types

- gold Open Access which fosters wider collaboration and increased citations

- maximum visibility for your research: over $100 \mathrm{M}$ website views per year

At $\mathrm{BMC}$, research is always in progress.

Learn more biomedcentral.com/submissions 